Article

\title{
Critical Factors Influencing the Adoption of Smart Home Energy Technology in China: A Guangdong Province Case Study
}

\author{
WeiYu Ji *(D) and Edwin H. W. Chan * \\ Department of Building and Real Estate, and Research Institute for Sustainable Urban Development, The Hong \\ Kong Polytechnic University, Kowloon 999077, Hong Kong, China \\ * Correspondence: wy.ji@connect.polyu.hk (W.J.); edwin.chan@polyu.edu.hk (E.H.W.C.)
}

Received: 22 September 2019; Accepted: 30 October 2019; Published: 1 November 2019

check for updates

\begin{abstract}
Smart home energy technology has been verified to be successful for energy reduction in the residential sector. However, the current penetration rate of smart home energy technology is at a low level. Considering the factors of economy, policy, and demographics, Guangdong Province in China is a suitable region as an exemplary case to promote smart home energy technology through the urban residents. Therefore, using Guangdong as the targeting area, this research examined the factors influencing residents' intention to adopt smart home energy technology. A theoretical model based on the theory of planned behavior and Norm Activation Model theory was developed, with special consideration of the complex technical features. A questionnaire survey was performed in Guangdong Province and the data was analyzed by PLS-SEM. The analysis results indicated that residents' attitude towards technical performance, social norm, perceived behavioral control, and personal norm all have positive influence on the adoption intention, of which, attitude towards technical performance had the strongest effect. On the other hand, the attitude towards economic performance was found not to lead adoption intention. To explain this consequence, the discussion based on behavioral economics was proposed.
\end{abstract}

Keywords: smart home energy technology; household energy saving; theory of planned behavior; norm activation model; structural equation modelling; energy efficiency gap; behavioral economics

\section{Introduction}

Globally, the residential sector is responsible for $20 \%$ of the total energy consumption, and this is expected to increase by $10 \%$ until 2040 due to the growth of population, economic development and improvement of living standards [1,2]. Many technologies have been developed and engaged to solve the energy efficiency problem of residential buildings. In recent years, with the rapid development of information and communication technology (ICT) and smart grids, smart home technology (SHT) has become a promising measure to benefit home occupant's living environment and improve living quality. One important category of SHT is smart home energy technology (SHET), particularly aiming to provide energy management services or energy reduction measures to residents [3,4]. SHET includes integrated systems or isolated components to manage the demand side of a smart grid by monitoring and arranging the home electricity consumption and various smart home appliances [5]. SHET achieves its energy management goals in two ways: (1) providing residents with their energy consumption information, to help residents cultivate energy saving behaviors; and (2) providing residents the ability to control the domestic appliances which can be scheduled or optimized via smart devices, so that they can utilize some electricity tariff policies to cut their energy bills [5-7].

Under the pressure of reducing the energy consumption of residential sector, several country governments have proposed various policies or strategies to promote the use of smart technology 
in home energy saving, such as the European Commission's "Create technologies and services for smart homes that provide smart solutions to energy consumers" [8] and the Smart Hong Kong plan "Promote and support households to utilize smart home mobile apps to monitor household energy consumption and set targets" [9]. In Singapore, some households were selected to install a home energy management system (HEMS) in a collaboration between the government and Panasonic [10].

Lots of previous research has focused on the technical issues of smart home energy technology. Karlin categorized the current SHET into three groups: user interfaces, including energy portal, in-home display, load monitor; and smart hardware, including smart appliance, smart light, smart thermostat, smart plug/switch as well as software platforms, such as smart home/web service platform [6]. The energy-saving capacity of each category of SHET have been demonstrated by many studies [7,11-14]. Louis et al. focused their attention on the environmental impacts of home energy systems during their lifecycle, and pointed out the energy payback time would be 1.6 years [15].

Additionally, several researchers have worked on topics related to the adoption and diffusion of smart home energy technology. Balta-Ozkan organized expert interviews and questionnaire surveys in European countries, and investigated social barriers to smart home technology diffusion, including fitting to lifestyles, public administration, interoperability, reliability, privacy, trust, and cost; he also pointed out energy cost savings, improving quality of life, environment, and information transparency as the four main drivers of smart home market development $[8,16]$. In Singapore, Bhati analyzed the perceptions of households about the usage of smart energy technology, concluding that residents have high awareness of the energy efficiency and indoor comfort, but are also concerned about the problem of security and privacy [10]. Some articles have examined the factors determining the adoption intention of specific home energy technology such as energy efficient household appliances or home energy management systems in several different countries, including Korea, Malaysia, China and Pakistan [17-20].

However, the influential factors of adoption intention are highly affected by the regional culture or demographic situation [18,20]. When talking about China, it has a huge population of 1.4 billion, and the residential sector accounts for $30.6 \%$ of the total primary energy consumption [21]. Currently, the penetration rate of smart home energy technology in China is only $1.4 \%$, lower than the global average level of $1.67 \%$ [22]. What is more, the literature studying the adoption of SHET by Chinese urban residents is not adequate. More endeavor will be needed to investigate residents' perceptions towards SHET and the factors affecting resident's adoption intention. Bridging this research gap could provide support to policy decisions or market strategies to promote the adoption and diffusion of SHET in China.

The objective of this article is to contribute to the understanding of the perceptions about the smart home energy technology by Chinese urban residents and to analyze the behavioral, social, psychological factors explaining people's adoption intentions. To achieve this goal, the most developed province in China, Guangdong, was selected as the study area. Compared to other provinces, the Guangdong provincial government can be viewed as the most ambitious in constructing low carbon, green, smart cities; and has put forward a series of positive policies to encourage the development of IOT or smart technology related industries. Guangdong also possesses the largest technology industrial cluster focusing on the research and development of the smart technology products covering all aspects of people's living. However, no matter the successful implementation of government policies, or the continuous long-term development of smart industry, the technology adoption by the market is the most crucial task. The selection of Guangdong as targeting area, on the one hand, it could provide policy implications for the government, or investigate some market strategies for industry to promote the diffusion of SHET; on the other hand, the study of Guangdong Province can be a good example for other provinces in China. As building smart cities is a national development strategy formulated by the central government, the current problems appearing in Guangdong Province will also present in other places in the near future. 
The paper is structured as follows: Section 2 reviews the policy, economy and social environment of Guangdong Province; and the behavioral models employed by the study; Section 3 introduces the research methodology; Section 4 presents the result of data analysis. The analysis results are discussed in Sections 5 and 6 presents the conclusions.

\section{Literature Review}

\subsection{Background of Guangdong Proince}

Guangdong is located in the southern part of the country, bordering on Hong Kong and Macau. It is the birthplace of the reform and opening-up policy implemented in China. As the first pilot area of the market economy, it has been the driving force of the growth of Chinese economy and achieved the highest GDP among all the provinces and municipalities for several years [23]. The high-tech industry is a significant and strategic component of Guangdong's economy, especially the electronics, information and communication technology industry.

From the aspect of policy, the Guangdong provincial government has formulated a series of policies to support the development of the electronics and ICT industry, such as "Opinions on accelerating the development of the IOT and building smart Guangdong" in 2010; and "The 12th five-year plan for the development of high-end electronic information industry in Guangdong" in 2012. These policies emphasized the core of future work in the development of IOT technology and its application in building smart cities and urban residents' smart living. Additionally, the carbon reduction policies enacted by the Guangdong provincial government are even more aggressive than at the national level [24], enabling Guangdong to be a frontrunner in carbon reduction in China. In year 2018, in "The 13th five-year plan for Guangdong development", the local housing authority set new objectives for energy and carbon reduction in the building sector, such as energy renovation of existing buildings, implementation of energy efficiency technology, promotion of low carbon living style through residents, etc. [25]. All these efforts made by government will provide a good policy environment for the development of IOT technology, green building, and energy efficiency technology.

In addition to the government, China Southern Power Grid (CSPG), the state power enterprise which is in charge of the electricity supply of the whole of Guangdong, announced its "The 13th five-year plan for smart grid development". Under the vision of CSPG, a comprehensive smart grid system will be built, with attributes of clean electricity generation, flexible electricity distribution, interactive electricity consumption, and integration with internet and information technology [26].

As for the demographic factors, Guangdong is the most populous province in China, hosting $8 \%$ of the total population, among which $75.4 \%$ are young and middle aged (15-64 years old), higher than the national average level (71.8\%); and only $7.7 \%$ are in the old group ( $>65$ years old) [27]. Guangdong has the largest group of young and middle aged labor force compared to other provinces. Referring to Diffusion of Innovation Theory, younger people are more likely to be the early adopters of new technology [28]. Venkatesh also empirically verified that the younger would have a stronger perception about the performance of new information technology in his research about technology adoption [29]. Besides, some previous studies found out the younger generation had higher intention to use the energy efficient technology, including the heating innovation facilities [30], micro-generation technology [31], and energy management system [32]. Therefore, considering the demographic factors, the local policies, and the strategy of the power company, Guangdong is an ideal place to actively promote the smart home energy technology through urban residents.

\subsection{Background of Behavioral Theory}

The theory of planned behavior (TPB), developed by Ajzen, has become one of the most important theoretical foundations to study human behavior. TPB points out human's behavior intentions are affected by the attitudes, subjective norms and perceived behavior control (PBC), as Figure 1 showing. According to Ajzen's theory, attitude is reflected by people's beliefs about the outcomes of performing 
a certain behavior; subjective norms are people's perceptions about the social pressure to engage or not to engage in a behavior; and perceived behavioral control refers to people's perceptions of their ability to perform a given behavior [33].

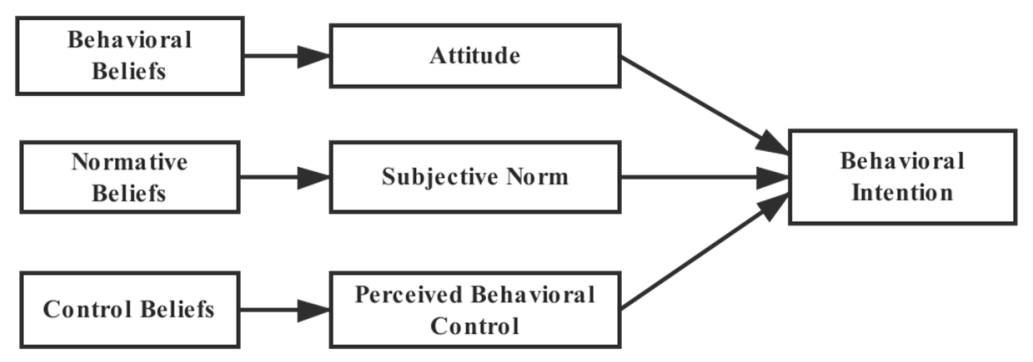

Figure 1. Theory of Planned Behavior Diagram (Reproduced with permission from [33], Elsevier, 1991).

In the TPB model, the subjective norm (SN) construct is affected by the prevailing external values in the social environment. In many previous studies, the power of personal norms in explaining the pro-environmental behaviour or altruistic behaviour has been demonstrated [34-36]. In the Norm Activation Model (NAM) theory proposed by Schwartz [37], the term "personal norm" was defined as the self-expectations or commitments under one's internal values and reflect one's feelings about the obligations to engage in a specific behaviour [37,38]. Personal norms will have influence on the behaviour intention when someone aware of the consequence $(A C)$ of its behaviour for the benefit of others or one's ascription of the responsibility (AR) for those consequences to oneself $[37,39,40]$.

Therefore, some studies have combined the TPB with the NAM to improve the explaining power of TPB, considering both factors of internal personal norms and external social values. A list of previous studies in the context of energy saving or pro-environmental behavior is shown in Table 1. However, given the complexity of human behavior and human nature, the current theories and studies are not capable to cover all the social and psychological factors as well as personal traits relevant with energy saving behavior $[19,41]$.

Generally, the energy saving behavior includes two fundamental categories: habitual behavior and purchasing behavior $[42,43]$. The habitual energy saving behavior refers to some daily activities to reduce the energy consumption such as setting thermostats lower, turning lights off when leaving a room, unplugging appliances after usage, etc. [43,44]. The purchasing energy saving behavior, also called "technology choice" [42], requires home retrofitting and financial investment in new energy efficiency technologies [43,45], such as installation of home energy management systems [32] and purchasing energy labeled appliances [20]. The scope of this paper will focus on the purchasing behavior in the context of smart home energy technologies.

Table 1. A list of previous research about energy saving behavior with application of TPB and NAM.

\begin{tabular}{|c|c|c|c|c|}
\hline Source & Region & Context & Theory & Construct \\
\hline [41] & USA & $\begin{array}{l}\text { Workplace energy saving } \\
\text { behavior, e.g., turn off } \\
\text { light/monitor when } \\
\text { leaving }\end{array}$ & $\begin{array}{l}\text { Combination of } \\
\text { NAM and TPB }\end{array}$ & $\begin{array}{l}\text { Subjective norm, descriptive } \\
\text { norm, attitude, organization } \\
\text { support, opportunity, } \\
\text { motivation, personal norm, } \\
\text { awareness of consequence, } \\
\text { ascription of responsibility, } \\
\text { ability, perceived behavioral } \\
\text { control, perceived knowledge, } \\
\text { actual knowledge }\end{array}$ \\
\hline
\end{tabular}


Table 1. Cont.

\begin{tabular}{|c|c|c|c|c|}
\hline Source & Region & Context & Theory & Construct \\
\hline [20] & Malaysia & $\begin{array}{l}\text { purchase intention for } \\
\text { energy-efficient } \\
\text { household }\end{array}$ & $\begin{array}{l}\text { Moral extension of } \\
\text { TPB }\end{array}$ & $\begin{array}{l}\text { Attitude, subjective norm, } \\
\text { perceived behavioral control, } \\
\text { environmental concern, } \\
\text { environmental knowledge, } \\
\text { moral norm, }\end{array}$ \\
\hline [46] & China & $\begin{array}{l}\text { household } \\
\text { PM2.5-reduction } \\
\text { behavior }\end{array}$ & $\begin{array}{l}\text { Combination of } \\
\text { NAM and TPB }\end{array}$ & $\begin{array}{l}\text { Subjective norm, descriptive } \\
\text { norm, attitude, perceived } \\
\text { behavioral control, moral } \\
\text { norm, environmental concern }\end{array}$ \\
\hline [47] & Brazil & $\begin{array}{l}\text { Energy saving behavior } \\
\text { of Industrial worker, e.g., } \\
\text { save the } \\
\text { electricity/gasoline onsite }\end{array}$ & $\begin{array}{l}\text { Combination of } \\
\text { TPB, NAM, } \\
\text { and human } \\
\text { reliability }\end{array}$ & $\begin{array}{l}\text { Attitude, subjective norm, } \\
\text { personal norm, perceived } \\
\text { behavioral control, } \\
\text { performance shaping factor }\end{array}$ \\
\hline [48] & Taiwan & $\begin{array}{l}\text { General energy savings } \\
\text { and carbon reduction } \\
\text { behaviors }\end{array}$ & $\begin{array}{l}\text { Moral extension of } \\
\text { TPB }\end{array}$ & $\begin{array}{l}\text { Attitude, subjective norm, } \\
\text { perceived behavioral control, } \\
\text { moral obligation }\end{array}$ \\
\hline [49] & China & $\begin{array}{l}\text { Complaint behavior } \\
\text { about the environmental } \\
\text { problem }\end{array}$ & $\begin{array}{l}\text { Combination of } \\
\text { TPB and NAM }\end{array}$ & $\begin{array}{l}\text { Attitude, subjective norm, } \\
\text { personal norm, perceived } \\
\text { behavioral control, awareness } \\
\text { of consequence }\end{array}$ \\
\hline [44] & China & $\begin{array}{l}\text { residents' habitual } \\
\text { energy-saving behavior }\end{array}$ & $\begin{array}{l}\text { Combination of } \\
\text { TPB and NAM }\end{array}$ & $\begin{array}{l}\text { Attitude, social norm, } \\
\text { personal norm, perceived } \\
\text { behavioral control, awareness } \\
\text { of consequence, ascription of } \\
\text { responsibility, save money, } \\
\text { policy environment }\end{array}$ \\
\hline
\end{tabular}

\subsection{Research Hypothesis}

Based on the above literature reviews of the behavioral model, this article introduces the construct personal norm from NAM and develops an extended TPB model, in order to strengthen the explaining power of TPB for moral dimension. Additionally, considering the complicated technical features of smart technology, and the potential monetary gains or cost incurred, the original construct "attitude" in TPB could not provide enough explanations covering all aspects of SHET. Therefore, with the purpose to better understand residents' perceptions about the technical and economic performance of SHET, two new attitudinal constructs are developed in this study: one is attitude towards technical performance (ATTP), the other is attitude towards economic performance (ATEP), as shown in Figure 2.

The measurement indicators assessing each model construct are obtained from the literature reviews. The specific explanations of the constructs and measurement indicators in this theoretical model are described in the following sections. 


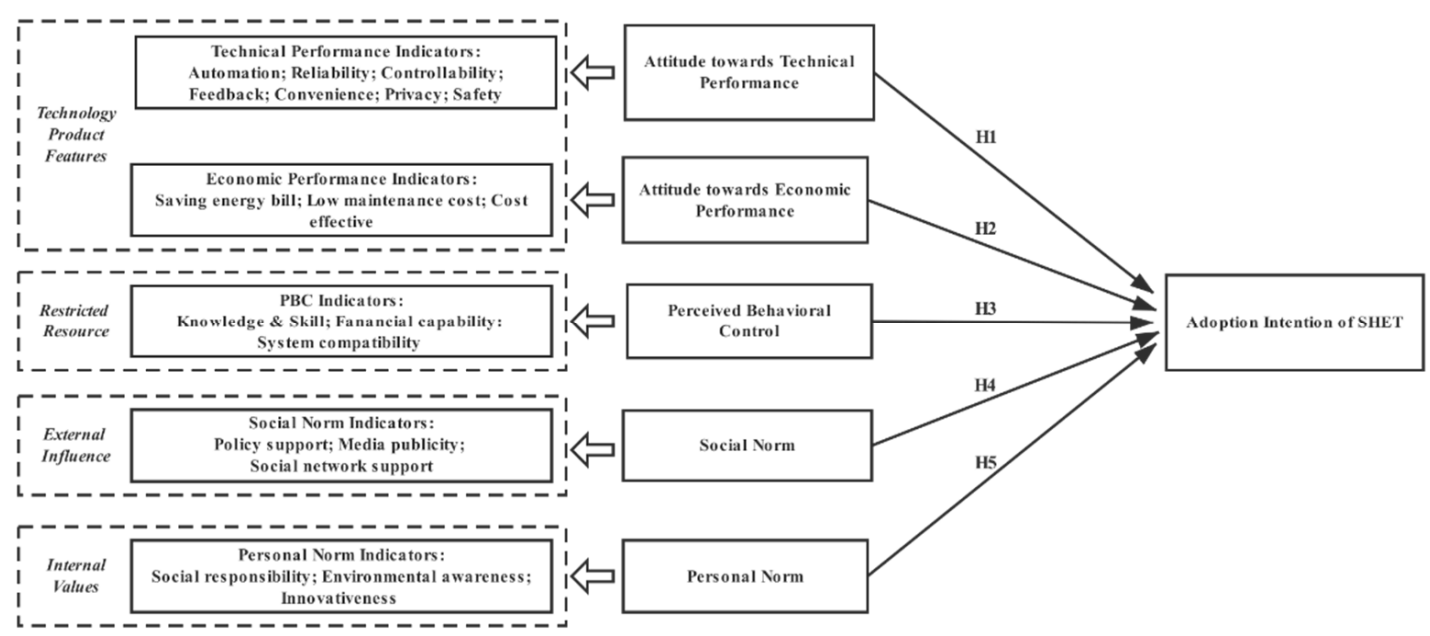

Figure 2. Theoretical research model describing the intention to adopt SHET.

\subsubsection{Residents' Attitude towards Adoption Intention of SHET}

Attitude is decided by one's subjective evaluation of the probable outcome that a behavior will produce [33]. It is a mental state of readiness that person learns through experience, and exerts influence on people's response [50]. In the study of household electricity-saving behavior performed by Wang [51], the attitude was decided by a household's evaluation of preference for electricity saving and the availability of information. Liu pointed out that residents' attitudes towards green buildings were affected by their perceptions about the usefulness and environmental awareness [52]. In the context of adoption of smart home energy technology (SHET), attitude represents the residents' evaluation of the performance that the SHET will present.

Currently, the smart technology is still under development, constantly providing new features to users. As smart home technology is expected to be involved deeply in people's life, and awareness of residents' daily activities, preference, or living habits [53], the smart living experience is very crucial when residents are making a decision about whether to adopt or not. Wong pointed out the technical (functional and operational) performance was an important factor influencing the adoption of smart home technologies [54]. Mert asserted that consumers' perception of a mature technology would determine one's willingness to use a smart appliance [55]. Here we come up with a hypothesis that residents' attitude towards technical performance (ATTP) of SHET is positively related with the adoption intention of SHET. In total seven categories of measurement indicators relevant with technical performance are investigated from previous studies, including: information feedback [7], automation, controllability [56], reliability ([16,54], convenience [57], privacy protection and safety $[8,16,55,58,59]$.

Moreover, a consumer study about smart domestic appliances organized in five European countries (Austria, Germany, Italy, Slovenia and UK) discovered that consumers' adoption intention would depend on their perceptions about financial benefit [55]. A higher expected monetary gains and shorter payback period would improve the evaluation of the smart home equipment [57]. Balta-Ozkan also conducted a comparative study about consumers' perceptions about smart home technology in the UK, Germany and Italy, revealing that people's perception of the economic performance, such as reducing energy cost was one key driver for smart home adoption in the three European countries [59]. Wong pointed out a low maintenance cost during the usage phase is a significant indicator of good economic performance [54]. The benefits of energy cost saving, lower payback period, and higher net present value of smart home technology solutions were demonstrated by experimental simulation for single family houses in Germany and Algeria [60]. Hence, based upon the previous research and literature reviewed, we expect that resident's attitude towards economic performance (ATEP) of SHET will have a positive impact on the adoption intention, and three measurement indicators of economic performance are investigated: save energy expense, low maintenance cost, and cost effective. The two hypothesis about attitude are listed below: 
H1: Residents' attitude towards technical performance of smart home energy technology is positively related with the adoption intention.

H2: Residents' attitude towards economic performance of smart home energy technology is positively related with adoption intention.

\subsubsection{Perceived Behavioral Control}

Perceived behavioral control ( $\mathrm{PBC}$ ) is defined as people's perceptions of their ability to perform a given behavior, and determined by the capabilities or resources that can facilitate the performance of this behavior under people's perceptions [33]. PBC can reflect two dimensions of concept: the first is about the availability of some external factors, such as money, time or other resources; while the other is about the internal factors, like self-confidence in the ability to perform one specific behavior $[33,61]$. Besides, as the smart technology is still developing, and new products or features will be released to market continually, the technical compatibility of the smart products with existing building systems, as well as with other smart products is important [16]. Four measurement indicators of PBC are chosen from the past literature, including knowledge and skills, financial capability, compatibility with existing building system, compatibility with other smart products.

In the previous research about the energy saving or environmental friendly behaviors, perceived behavioral control has been widely adopted into the theoretical model, and confirmed as a significant factor influencing the behavioral intention, including [18,20,62-64]. Saqib Ali [19] verified that PBC is positively related to resident's purchase intention of household energy efficient appliances through a questionnaire survey in Pakistan. Therefore, this study has a similar expectation about PBC, and develop the below hypothesis:

H3: Perceived behavioral control has a positive relation with resident's intention to adopt SHET.

\subsubsection{Social Norm}

Social norms, also named subjective norms, are defined by Ajzen as the perceived social pressures to engage or not to engage in a behavior and related with the expectations of important referents, such as friends, family members etc. [33]. Cialdini categorized the social norm into two types: injunctive norm and descriptive norm $[65,66]$. The injunctive norm refers to whether one behavior can be supported by the majority of social group, while the descriptive norm reflects a popular behavior welcomed by the society [66]. According to the Theory of Diffusion of Innovation [28], in the decision-making process of a new technology adoption, people will be influenced by factors from the external environment, such as mass media, government policy or regulations, and their social network [67]. In a comparative study of household energy saving behaviors in five Asian countries conducted by Hori [68], the significance of social interaction factors such as "favoring neighborhood" and "participating in community" is investigated through questionnaire survey. Wang also verified the significance of policy in determining Beijing resident's electricity saving behavior [51]. Therefore, policy environment, media publicity, and support from social network are selected as measurement indicators to reflect the factor of Social Norm (SN). The indicator "support from social network" reflects the type of injunctive norm; and the other two indicators reflect the type of injunctive norm. Based on the previous research, one hypothesis is developed:

H4: Social norms have a positive influence on resident's intention to adopt SHET.

\subsubsection{Personal Norm}

Personal norm (PN) is defined as the self-expectations or commitments under one's internal values and reflect one's feelings about the obligations to engage in a specific behavior [37,38]. Personal norms will have influence on the behavior intention when someone aware of the consequence (AC) of its 
behavior for the benefit of others or one's ascription of the responsibility (AR) for those consequences to oneself $[37,39]$. The impact of personal norm onto the motivation of energy saving or carbon reduction behavior has been verified by numerous past research [41,48,69]. What is more, Ritu Agarwal suggested that the person with innovativeness in one's personal trait would be more likely to adopt new technology [70]. Saqib Ai also confirmed the role of innovativeness as a human trait to influence consumers' attitude towards energy efficient appliances [19]. In a consumer acceptance analysis of home energy management system (HEMS) for Korean market, the authors identified social contribution, environmental responsibility, and innovativeness as influential factors [17]. In this study, referring to the previous studies, three measurement indicators are selected to assess the factor personal norm (PN), including social responsibility, environmental awareness, and innovativeness. The fifth hypothesis for the resident's intention to adopt SHET is proposed:

H5: Personal norm is positively related to resident's adoption intention for SHET.

A summary of the factors, measurement indicators of factors, as well as the description of indicators and their sources highlighted in the literature is provided in Table 2.

Table 2. Summary of influential factors and measurement indicators.

\begin{tabular}{|c|c|c|c|}
\hline Factor & Measurement Indicator & Description of Indicator & Source \\
\hline \multirow{11}{*}{$\begin{array}{l}\text { Technical performance } \\
\text { attitude (ATTP) }\end{array}$} & Automation (TP1) & $\begin{array}{l}\text { SHET could achieve the automatic operation, require } \\
\text { minimized human intervention. }\end{array}$ & [56] \\
\hline & Reliability (TP2) & $\begin{array}{l}\text { The operation of SHET will not suffer major failure } \\
\text { or malfunction. }\end{array}$ & {$[8,16]$} \\
\hline & Controllability (TP3) & $\begin{array}{l}\text { The operation of SHET could be under some } \\
\text { guideline, could work under interactive mode, could } \\
\text { be controlled by human via different methods. }\end{array}$ & {$[56,71]$} \\
\hline & Safety (TP4) & $\begin{array}{l}\text { Would not cause threaten to resident's personal and } \\
\text { property safety. }\end{array}$ & {$[8,16]$} \\
\hline & Feedback 1 (TP5) & $\begin{array}{l}\text { SHET could report household's total energy usage } \\
\text { information through smart devices, such as smart } \\
\text { phone, In Home Display, etc. }\end{array}$ & \multirow[t]{2}{*}{ [7] } \\
\hline & Feedback 2 (TP6) & $\begin{array}{l}\text { SHET could report household's appliance level } \\
\text { energy usage information. }\end{array}$ & \\
\hline & Feedback 3 (TP7) & $\begin{array}{l}\text { SHET could report household's energy consumption } \\
\text { level among the neighborhood. }\end{array}$ & [72] \\
\hline & Privacy 1 (TP8) & $\begin{array}{l}\text { SHET could ensure resident's personal privacy } \\
\text { would not be violated. }\end{array}$ & \multirow{2}{*}[8,16,55]{} \\
\hline & Privacy 2 (TP9) & $\begin{array}{l}\text { Service providers of SHET will not violate the } \\
\text { privacy right of resident. }\end{array}$ & \\
\hline & Convenience 1 (TP10) & $\begin{array}{l}\text { The functions and design of SHET could enable } \\
\text { resident to use it conveniently. }\end{array}$ & \multirow{5}{*}[54,55,59]{} \\
\hline & Convenience 2 (TP11) & $\begin{array}{l}\text { The functions of SHET could improve resident's } \\
\text { living comfort. }\end{array}$ & \\
\hline \multirow{3}{*}{$\begin{array}{l}\text { Economic performance } \\
\text { attitude (ATEP) }\end{array}$} & Energy expense saving (EP1) & SHET could help household to save energy bill. & \\
\hline & Low maintenance cost (EP2) & SHET will not need high maintenance cost. & \\
\hline & Cost effective (EP3) & $\begin{array}{l}\text { Considering cost of purchase and installation, } \\
\text { the SHET is cost effective. }\end{array}$ & \\
\hline \multirow{4}{*}{$\begin{array}{l}\text { Perceived behavioral } \\
\text { control }(\mathrm{PBC})\end{array}$} & Knowledge Skill (PBC1) & $\begin{array}{l}\text { Residents need master enough knowledge and skill } \\
\text { to adopt SHET. }\end{array}$ & \multirow{2}{*}[33,61]{} \\
\hline & Financial Capability (PBC2) & $\begin{array}{l}\text { Residents need enough financial capability to adopt } \\
\text { SHET. }\end{array}$ & \\
\hline & $\begin{array}{l}\text { Compatibility with building } \\
\text { system(PBC3) }\end{array}$ & $\begin{array}{l}\text { The building system of existing home could be } \\
\text { compatible with smart home energy products. }\end{array}$ & \multirow{2}{*}{ [16] } \\
\hline & $\begin{array}{l}\text { Compatibility with smart } \\
\text { product(PBC4) }\end{array}$ & $\begin{array}{l}\text { The existing smart home energy products could be } \\
\text { compatible with other products in market. }\end{array}$ & \\
\hline
\end{tabular}


Table 2. Cont.

\begin{tabular}{cll}
\hline \multicolumn{1}{c}{ Factor } & \multicolumn{1}{c}{ Measurement Indicator } & \multicolumn{1}{c}{ Description of Indicator } \\
\hline \multirow{2}{*}{ Social norm (SN) } & Policy Support (SN1) & $\begin{array}{l}\text { Government's subsidy policies on tax and price or } \\
\text { other polices to facilitate the adoption of SHET }\end{array}$ \\
\cline { 2 - 3 } & Media Publicity (SN2) & $\begin{array}{l}\text { The marketing or advertisement information of } \\
\text { SHET on mass media. }\end{array}$ \\
\cline { 2 - 3 } Personal norm (PN) & Social Network Support (SN3) & $\begin{array}{l}\text { The support from family and members of social } \\
\text { network about SHET adoption. }\end{array}$ \\
\cline { 2 - 4 } & Environmental concern (PN2) & $\begin{array}{l}\text { The resident deem oneself has the responsibility to } \\
\text { adopt for the future of society. } \\
\text { protection. }\end{array}$ \\
\cline { 2 - 4 } & Innovativeness (PN3) & $\begin{array}{l}\text { The resident have interest on the technology } \\
\text { innovation, }\end{array}$ \\
\hline
\end{tabular}

\section{Methodology}

\subsection{Questionnaire Survey Design and Data Collection}

A quantitative analysis based on a questionnaire survey was employed in this study. Survey questions were developed from the literature highlighted in the above sections, and the questionnaire survey included two parts. The first part collected the demographic information of respondents, including gender, age, educational level, household income, and usage experience of SHET. The second part included the questions aiming to measurement indicators. The Likert Scale measurement method has been applied in many studies to analyze the questionnaire survey, such as $[19,20,46,73-75]$. A five-point Likert scale is developed to measure variables in the survey, ranging from $1=$ strongly disagree to $5=$ strongly agree. Then the questionnaire survey was distributed by an internet based survey system to urban residents in Guangdong Province.

The survey was carried out from February 2019 to March 2019. A total of 2600 questionnaires were distributed and 2391 responses returned, with a $92 \%$ respondent rate. During the data screening process, the responses with missing value or the resources from rural village were removed. Finally, 1913 responses were retained to make up the sample for the SEM analysis. Table 3 introduces the demographic information for the respondents, showing that the percentage of male respondents $(60 \%)$ is higher than that of females (40\%); $93.2 \%$ of the respondents are young and middle aged (18-60 years old); $63.8 \%$ of the respondents have a university degree or above; and a higher portion of respondents had experience of using SHET.

\subsection{Structural Equation Modelling}

Structural equation modelling (SEM) was employed to analyse the relationship between the model constructs and test the hypothesis. In recent years, SEM has become the most important and influential statistical method in social science research [76]. As a second generation multivariate analysis technique, SEM could achieve the assessment of both measurement model and structural model simultaneously by combining the functions of two powerful statistical methodologies: exploratory factor analysis and linear regression analysis [77,78]. SEM has two dominating approaches: covariance-based SEM (CB-SEM) and variance-based partial least squares (PLS-SEM). Compared to CB-SEM, PLS-SEM has some flexibilities and advantages in the less limitations of sample size, no strict requirement of data normality, and encompassing various formats and large number of variables [79-81]. Hence PLS-SEM has gained popularity in many research fields such as strategic management [82], information system [83], business management [84,85], tourism management [86], accounting [78], technology adoption by construction industry [87], and marketing [88]. 
Table 3. The demographic information for the respondents.

\begin{tabular}{|c|c|c|c|}
\hline Demographic Category & Factor & Frequency & Percentage (\%) \\
\hline \multirow{2}{*}{ Gender } & Male & 1147 & 60.0 \\
\hline & Female & 766 & 40.0 \\
\hline \multirow{4}{*}{ Age } & Juvenile $(\leq 18)$ & 66 & 3.5 \\
\hline & Young Adult (18-40) & 1348 & 70.5 \\
\hline & Middle Age (41-60) & 435 & 22.7 \\
\hline & Old $(\geq 60)$ & 64 & 3.3 \\
\hline \multirow{2}{*}{ Education } & Below Bachelor & 692 & 36.2 \\
\hline & Bachelor and above & 1221 & 63.8 \\
\hline \multirow{3}{*}{$\begin{array}{l}\text { Personal Annual Income } \\
\text { (10 thousand yuan) }\end{array}$} & Poor $(0-10)$ & 516 & 27.0 \\
\hline & Middle Class (10-30) & 1228 & 64.2 \\
\hline & Affluent $(\geq 30)$ & 169 & 8.8 \\
\hline \multirow{2}{*}{$\begin{array}{c}\text { Usage Experience of } \\
\text { SHET }\end{array}$} & Have experience & 1300 & 68.0 \\
\hline & No experience & 613 & 32.0 \\
\hline
\end{tabular}

In Table 3, under age category, the sub-sample of Juvenile and Old is quite small (66 and 64 respectively). Table 4 presents the normality test result for measurement indicators, and the $p$ value shows that the data doesn't conform to a normal distribution. Therefore, considering the applicability and data requirements of CB-SEM and PLS-SEM, this study will employ PLS-SEM to analyse the theoretical model. The execution of PLS-SEM will be performed by the software SmartPLS 3 [89] (SmartPLS 3.2.8, SmartPLS GmbH, Hamburg, Germany) by three processes: (a) assessment of measurement model, (b) assessment of structure model, and (c) assessment of significance of path coefficient $[90,91]$. The detailed results will be presented in the following section.

Table 4. Test result of normal distribution.

\begin{tabular}{|c|c|c|c|c|c|c|}
\hline Measurement Indicator & Mean & Std. & Skewness & Kurtosis & Statistic & $p$-value \\
\hline Automation (TP1) & 3.988 & 1.121 & -1.147 & 0.675 & 0.254 & $0.000 * *$ \\
\hline Reliability (TP2) & 3.891 & 1.126 & -0.926 & 0.147 & 0.239 & $0.000 * *$ \\
\hline Controllability (TP3) & 3.961 & 1.1 & -1.112 & 0.667 & 0.262 & $0.000 * *$ \\
\hline Safety (TP4) & 3.906 & 1.134 & -0.994 & 0.28 & 0.25 & $0.000 * *$ \\
\hline Feedback 1 (TP5) & 4.013 & 1.122 & -1.256 & 0.96 & 0.271 & $0.000 * *$ \\
\hline Feedback 2 (TP6) & 4.014 & 1.084 & -1.192 & 0.884 & 0.267 & $0.000 * *$ \\
\hline Feedback 3 (TP7) & 3.983 & 1.111 & -1.163 & 0.747 & 0.265 & $0.000 * *$ \\
\hline Privacy 1 (TP8) & 3.837 & 1.184 & -0.953 & 0.068 & 0.257 & $0.000 * *$ \\
\hline Privacy 2 (TP9) & 3.845 & 1.177 & -0.92 & -0.007 & 0.25 & $0.000 * *$ \\
\hline Convenience 1 (TP10) & 3.982 & 1.059 & -1.133 & 0.812 & 0.275 & $0.000^{* *}$ \\
\hline Convenience 2 (TP11) & 4.058 & 1.084 & -1.319 & 1.226 & 0.278 & $0.000 * *$ \\
\hline Energy expense saving (EP1) & 3.98 & 1.101 & -1.141 & 0.699 & 0.267 & $0.000 * *$ \\
\hline Low maintenance cost (EP2) & 3.847 & 1.151 & -0.904 & 0.031 & 0.25 & $0.000 * *$ \\
\hline Cost effective (EP3) & 3.926 & 1.098 & -1.072 & 0.604 & 0.265 & $0.000 * *$ \\
\hline Knowledge Skill (PBC1) & 4.01 & 1.081 & -1.176 & 0.841 & 0.267 & $0.000 * *$ \\
\hline Financial Capability (PBC2) & 3.957 & 1.096 & -1.076 & 0.568 & 0.259 & $0.000 * *$ \\
\hline Compatibility with building system (PBC3) & 3.93 & 1.088 & -1.079 & 0.659 & 0.266 & $0.000 * *$ \\
\hline Compatibility with smart product (PBC4) & 3.947 & 1.101 & -1.08 & 0.588 & 0.26 & $0.000 * *$ \\
\hline Policy Support (SN1) & 3.868 & 1.133 & -0.949 & 0.204 & 0.251 & $0.000 * *$ \\
\hline Media Publicity (SN2) & 3.842 & 1.143 & -0.898 & 0.067 & 0.246 & $0.000 * *$ \\
\hline Social Network Support (SN3) & 3.876 & 1.141 & -0.952 & 0.172 & 0.249 & $0.000 * *$ \\
\hline Social responsibility (PN1) & 3.876 & 1.131 & -0.972 & 0.253 & 0.256 & $0.000 * *$ \\
\hline Environmental concern (PN2) & 3.913 & 1.086 & -1.018 & 0.501 & 0.262 & $0.000^{* *}$ \\
\hline Innovativeness (PN3) & 3.978 & 1.085 & -1.124 & 0.731 & 0.263 & $0.000 * *$ \\
\hline
\end{tabular}




\section{Analysis Results}

\subsection{Assessment of Measurement Model}

The measurement model is the outer model of SEM, representing the relationships between the latent variable construct and the associated indicator variables [92]. The measurement model will be evaluated by two types of validity:

- $\quad$ Convergent validity: outer loadings of indicators $>0.7$; composite reliability (CR) $>0.7$ and the average variance extracted $(\mathrm{AVE})>0.5$ [90], meaning that the indicators are reliable and more than half of the indicator variance is included in the construct [91];

- Discriminant validity: to evaluate whether a construct in SEM is unique from others [92], the criteria is square root of AVE of one construct should be higher than the correlation coefficient shared by this construct and any other constructs [90].

The assessment result of convergence validity is presented in Table 5, where all of the indicator loadings are higher than 0.7 , meaning that all the measurement indicators are reliable and can be retained in the model. Both the value of Cronbach's $\alpha$ and Composite Reliability (CR) are more than 0.7 , satisfying the requirement of internal consistency; and the value of average variance extracted (AVE) ranges from 0.662 to 0.759 , indicating the constructs in the model could explain at least $66 \%$ of the indicator variance, according to the recommendation by Hair et al. $[90,91]$, the convergent validity of the measurement model could be convinced.

Table 5. Assessment of measurement model: convergent validity.

\begin{tabular}{|c|c|c|c|c|c|}
\hline Latent Variable & Measurement Indicator & Loading & $\begin{array}{l}\text { Cronbach's } \\
\text { Alpha }\end{array}$ & $\begin{array}{l}\text { Composite } \\
\text { Reliability }\end{array}$ & $\begin{array}{l}\text { Average Variance } \\
\text { Extracted (AVE) }\end{array}$ \\
\hline \multirow{11}{*}{$\begin{array}{c}\text { Technical } \\
\text { performance } \\
\text { attitude }(\mathrm{ATTP})\end{array}$} & Automation (TP1) & 0.816 & \multirow{11}{*}{0.949} & \multirow{11}{*}{0.956} & \multirow{11}{*}{0.662} \\
\hline & Reliability (TP2) & 0.805 & & & \\
\hline & Controllability (TP3) & 0.822 & & & \\
\hline & Safety (TP4) & 0.817 & & & \\
\hline & Feedback 1 (TP5) & 0.823 & & & \\
\hline & Feedback 2 (TP6) & 0.814 & & & \\
\hline & Feedback 3 (TP7) & 0.826 & & & \\
\hline & Privacy 1 (TP8) & 0.789 & & & \\
\hline & Privacy 2 (TP9) & 0.786 & & & \\
\hline & Convenience 1 (TP10) & 0.818 & & & \\
\hline & Convenience 2 (TP11) & 0.833 & & & \\
\hline \multirow{3}{*}{$\begin{array}{c}\text { Economic } \\
\text { performance } \\
\text { attitude }(\mathrm{ATEP})\end{array}$} & Energy expense saving (EP1) & 0.870 & \multirow{3}{*}{0.837} & \multirow{3}{*}{0.902} & \multirow{3}{*}{0.754} \\
\hline & Low maintenance cost (EP2) & 0.855 & & & \\
\hline & cost effective (EP3) & 0.880 & & & \\
\hline \multirow{4}{*}{$\begin{array}{c}\text { Perceived } \\
\text { behavioral } \\
\text { control (PBC) }\end{array}$} & Knowledge Skill (PBC1) & 0.847 & \multirow{4}{*}{0.880} & \multirow{4}{*}{0.917} & \multirow{4}{*}{0.735} \\
\hline & Financial Capability (PBC2) & 0.858 & & & \\
\hline & $\begin{array}{c}\text { Compatibility with building } \\
\text { system (PBC3) }\end{array}$ & 0.863 & & & \\
\hline & $\begin{array}{l}\text { Compatibility with smart } \\
\text { product (PBC4) }\end{array}$ & 0.859 & & & \\
\hline \multirow{3}{*}{ Social norm (SN) } & Policy Support (SN1) & 0.874 & \multirow{3}{*}{0.841} & \multirow{3}{*}{0.904} & \multirow{3}{*}{0.759} \\
\hline & Media Publicity(SN2) & 0.863 & & & \\
\hline & Social Network Support (SN3) & 0.876 & & & \\
\hline \multirow{3}{*}{$\begin{array}{l}\text { Personal norm } \\
\qquad(\mathrm{PN})\end{array}$} & Social responsibility (PN1) & 0.866 & \multirow{3}{*}{0.840} & \multirow{3}{*}{0.903} & \multirow{3}{*}{0.757} \\
\hline & Environmental concern (PN2) & 0.874 & & & \\
\hline & Interest of technology (PN3) & 0.869 & & & \\
\hline
\end{tabular}


Table 6 introduces the assessment result of discriminant validity. As presented in Table 6, the square root of AVE of one construct (the numbers on the diagonal line) is higher than the correlation coefficient shared by this construct and any other constructs, referring to [90,92], the measurement model has achieved enough discriminant validity, implying the uniqueness of each construct compared with others.

Table 6. Assessment of measurement model: discriminant validity.

\begin{tabular}{cccccc}
\hline & $\begin{array}{c}\text { Technical } \\
\text { Performance } \\
\text { Attitude }\end{array}$ & $\begin{array}{c}\text { Economic } \\
\text { Performance } \\
\text { Attitude }\end{array}$ & $\begin{array}{c}\text { Perceived } \\
\text { Behavioral } \\
\text { Control }\end{array}$ & Social Norm & Personal Norm \\
\hline Technical performance attitude & 0.814 & & & & \\
Economic performance attitude & 0.781 & 0.869 & & & \\
Perceived behavioral control & 0.773 & 0.842 & 0.857 & & \\
Social norm & 0.781 & 0.831 & 0.823 & 0.871 & 0.870 \\
Personal norm & 0.804 & 0.817 & 0.824 & 0.824 & \\
\hline
\end{tabular}

\subsection{Assessment of the Structure Model}

The primary evaluation criteria for the structural model include the significance of path coefficient, the $\mathrm{R}^{2}$ measure, and Stone-Geisser's $\mathrm{Q}^{2}$ value [90]. In this study, the test of path coefficient significance is performed by 5000 samples of bootstrapping procedure and critical values of $T$ test is 2.33 , with the significance level of $0.01(* * p<0.01)$. As shown in Table 7 , the hypothetical test results suggest that hypotheses $\mathrm{H} 1, \mathrm{H} 3, \mathrm{H} 4, \mathrm{H} 5$ are supported, while $\mathrm{H} 2$ is rejected, meaning that the positive influences of attitude towards technical performance, perceived behavioural control, social norm, and personal norm onto the adoption intention of SHET are empirically supported by the study, however, resident's attitude towards economic performance of SHET could not be verified to have a positive relationship with adoption intention.

The $\mathrm{R}^{2}$ measure is to test the explaining power of the latent variables in the model. In the discipline of consumer behaviour, $R^{2}$ result of 0.20 is considered to be high, representing the model could well explain the research object [90]. Cohen suggested that in behavioural science, an $R^{2}$ value of 0.35 is substantial [93]. As Table 7 shows, the $\mathrm{R}^{2}$ value is 0.589 , representing that $58.9 \%$ of the variance in adoption intention of SHET could be explained by the five antecedent constructs in the proposed model. Besides, $Q^{2}$ value is a predominant method to evaluate the model's predictive relevance. The constructs in the model will exhibit predictive relevance if the $Q^{2}$ value (0.574) is larger than zero [90]. Figure 3 below is the complete graph of PLS-SEM results of path coefficient and indicator loadings.

Table 7. Assessment results of the structure model.

\begin{tabular}{|c|c|c|c|c|c|c|c|c|}
\hline Hypothesis & Relationship & Path Coefficient & SE & T-Value & $p$-Value & Supported & $\mathbf{R}^{2}$ & $\mathrm{Q}^{2}$ \\
\hline $\mathrm{H} 1$ & $\begin{array}{c}\text { Technical } \\
\text { performance attitude } \\
->\text { Adoption intention }\end{array}$ & 0.231 & 0.0461 & $5.004^{* *}$ & 0.000 & Yes & \multirow{5}{*}{0.589} & \multirow{5}{*}{0.574} \\
\hline $\mathrm{H} 2$ & $\begin{array}{c}\text { Economic } \\
\text { performance attitude } \\
->\text { Adoption intention }\end{array}$ & 0.020 & 0.0344 & $0.581^{* *}$ & 0.561 & No & & \\
\hline $\mathrm{H} 3$ & $\begin{array}{l}\text { Perceived behavioral } \\
\text { control -> Adoption } \\
\text { intention }\end{array}$ & 0.176 & 0.0353 & $4.990 * *$ & 0.000 & Yes & & \\
\hline $\mathrm{H} 4$ & $\begin{array}{c}\text { Social norm -> } \\
\text { Adoption intention }\end{array}$ & 0.208 & 0.0349 & $5.974^{* *}$ & 0.000 & Yes & & \\
\hline H5 & $\begin{array}{l}\text { Personal norm -> } \\
\text { Adoption intention }\end{array}$ & 0.180 & 0.0339 & $5.306 * *$ & 0.000 & Yes & & \\
\hline
\end{tabular}

Note: Bootstrap sample $=5000 .{ }^{* *}$ All T-values are significant at the 0.01 level. 


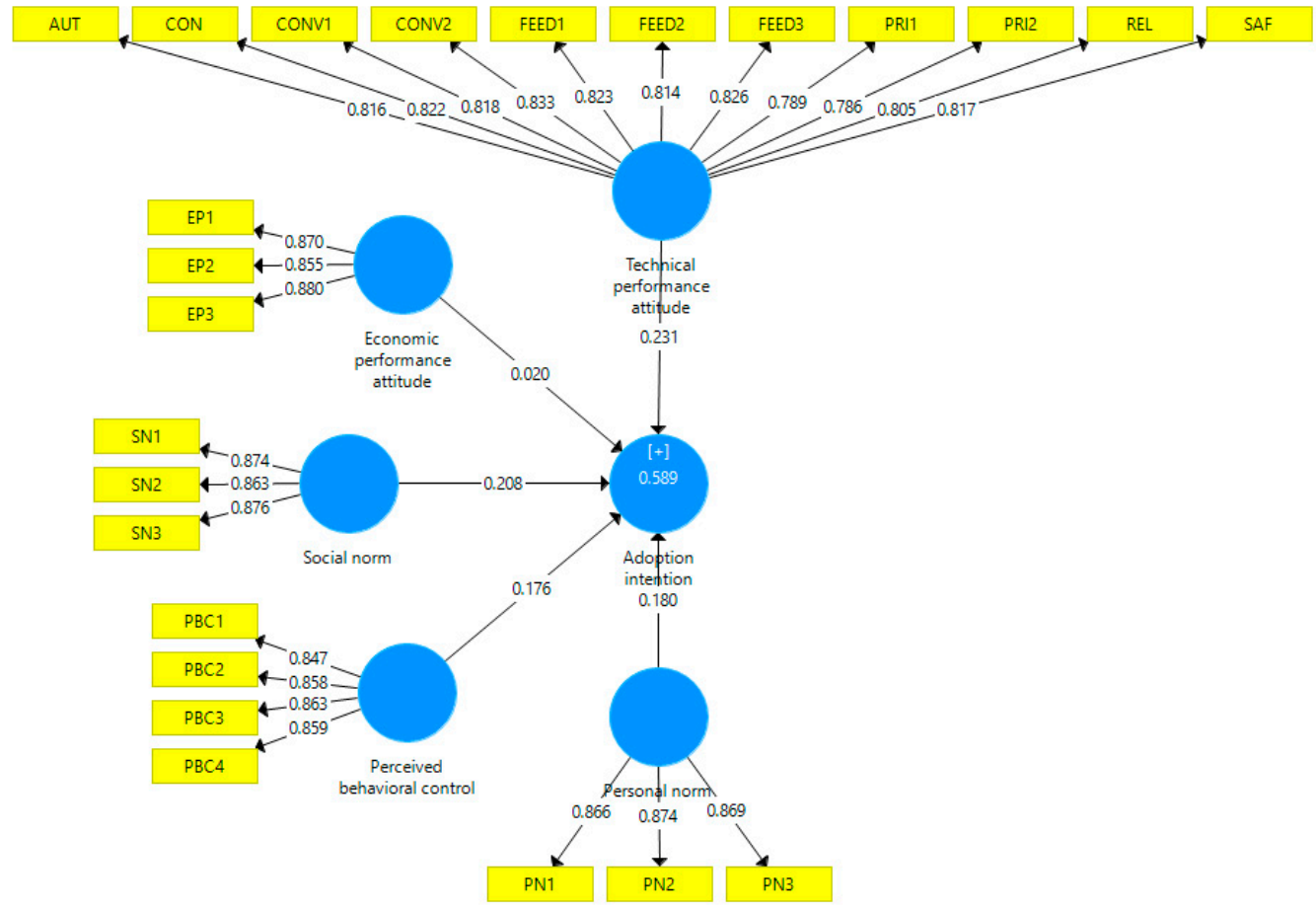

Figure 3. PLS-SEM [89] results of path coefficients and indicator loadings.

\subsection{Assessment of Hypothesis by Category of Demographic Information}

To further analyse whether the demographic factors (gender, age, education, personal income) would affect the hypothesis test results, the whole data group was divided into several sub-groups and PLS-SEM was re-executed for each sub-group, respectively. The details of the sub-groups and the hypothesis test results are shown in Table 8.

As presented by Table 8, under the demographic category of Gender, the hypothesis test result of male group is consistent with the test result of the whole group given in Table 7; however, for the female group, H5 is rejected, indicating that in this study, the personal norm of females would not lead to the adoption of SHET.

Under the category of Age, for the juvenile group, only $\mathrm{H} 1$ is supported with $\mathrm{H} 2-\mathrm{H} 5$ being rejected, indicating that the only influential factor for teenagers to adopt SHET is their attitudes towards the technical performance. For the groups of young and middle aged adults, the hypothesis test results are the same as the test results of the whole group. Particularly, for the old group, all five hypotheses are rejected, meaning that none of the factors discussed in this article would drive old people to welcome SHET.

As for educational level, compared to the test result of whole group, the group of below bachelor degree level rejected the hypothesis $\mathrm{H} 1$, signifying that people without university degrees will not accept the SHET under the influence of its technical performance, however, they will intend to use SHET because of the factors of social norm, perceived behavioural control, and personal norm, while for those people who received a university education and above, the hypothesis test results remain the same.

Taking personal annual income into consideration, there is no difference between the sub-groups of poor, middle class and the whole group, and they all support $\mathrm{H} 1, \mathrm{H} 3, \mathrm{H} 4, \mathrm{H} 5$ but reject $\mathrm{H} 2$. In contrast, affluent people, whose annual personal income is higher than 300,000 Yuan, support H1 and H2, but reject $\mathrm{H} 3-\mathrm{H} 5$. Especially for $\mathrm{H} 2$, the affluent is the only group whose attitude towards the economic performance will lead to the adoption intention of SHET. 
Table 8. Hypothesis test results by category of demographic information.

\begin{tabular}{|c|c|c|c|c|c|c|c|c|c|c|c|}
\hline & & \multicolumn{2}{|c|}{$\begin{array}{c}\text { H1: ATTP -> } \\
\text { Adoption Intention }\end{array}$} & \multicolumn{2}{|c|}{$\begin{array}{c}\text { H2: ATEP -> } \\
\text { Adoption Intention }\end{array}$} & \multicolumn{2}{|c|}{$\begin{array}{c}\text { H3: PBC -> } \\
\text { Adoption Intention }\end{array}$} & \multicolumn{2}{|c|}{$\begin{array}{l}\text { H4: Social Norm -> } \\
\text { Adoption Intention }\end{array}$} & \multicolumn{2}{|c|}{$\begin{array}{l}\text { H5: Personal Norm -> } \\
\text { Adoption Intention }\end{array}$} \\
\hline & & $p$-value * & Supported & $p$-value * & Supported & $p$-value * & Supported & $p$-value * & Supported & $p$-value * & Supported \\
\hline \multirow[b]{2}{*}{ Gender } & Male & 0.000 & Yes & 0.550 & No & 0.000 & Yes & 0.000 & Yes & 0.000 & Yes \\
\hline & Female & 0.007 & Yes & 0.092 & No & 0.028 & Yes & 0.000 & Yes & 0.080 & No \\
\hline \multirow{4}{*}{ Age } & Juvenile $(\leq 18)$ & 0.005 & Yes & 0.449 & No & 0.736 & No & 0.805 & No & 0.066 & No \\
\hline & Young Adult (18-40) & 0.000 & Yes & 0.826 & No & 0.000 & Yes & 0.000 & Yes & 0.000 & Yes \\
\hline & Middle Age (41-60) & 0.045 & Yes & 0.544 & No & 0.000 & Yes & 0.008 & Yes & 0.017 & Yes \\
\hline & Old $(\geq 60)$ & 0.389 & No & 0.733 & No & 0.114 & No & 0.052 & No & 0.274 & No \\
\hline \multirow{2}{*}{ Education } & Below bachelor & 0.066 & No & 0.132 & No & 0.000 & Yes & 0.007 & Yes & 0.000 & Yes \\
\hline & Bachelor and above & 0.000 & Yes & 0.837 & No & 0.000 & Yes & 0.000 & Yes & 0.000 & Yes \\
\hline \multirow{3}{*}{$\begin{array}{c}\text { Personal Annual } \\
\text { Income } \\
\text { (10 thousand Yuan) }\end{array}$} & Poor (0-10) & 0.000 & Yes & 0.879 & No & 0.000 & Yes & 0.000 & Yes & 0.000 & Yes \\
\hline & Middle Class (10-30) & 0.032 & Yes & 0.655 & No & 0.011 & Yes & 0.000 & Yes & 0.020 & Yes \\
\hline & Affluent $(\geq 30)$ & 0.004 & Yes & 0.019 & Yes & 0.572 & No & 0.230 & No & 0.401 & No \\
\hline
\end{tabular}

Note: Bootstrap sample $=5000 ;{ }^{*} p<0.05$. 


\section{Discussion}

\subsection{Attitude Towards Technical Performance}

Without consideration of demographic factors, the measurement model confirms that attitude towards technical performance (ATTP) will have a positive relationship with residents' adoption intention of SHET. The result implies that the residents who have favorable attitude towards the technical performances or functions will be more likely to purchase SHET products. This finding is consistent with the theory of Technology Adoption Model (TAM). TAM theory is specifically designed to explain the adoption behavior of information technology, implying that the factor "perceived usefulness", defined as "the degree to which that users believe that the useful functions of information technology" is found to have a positive influence onto the adoption intention [94,95]. Compared to traditional information technology such as computers, the smart technology displays more complicated technical features and is involved more deeply with people's daily life. The highest path coefficient between ATTP and adoption manifests that favorable perception of the complicated technical features of smart technology products (automation, reliability, controllability, safety, feedback, privacy protection, and convenience) is the strongest driver for residents' intention to use SHET. The demographic information shows that $68 \%$ of the total respondents have the usage experience of SHET, implying that the urban residents in Guangdong primarily demonstrate positive attitudes towards the technical functions of SHET. Therefore, in an effort to improve the adoption rate of SHET, smart home industry may regard the enhancement of technical performance and user experience as their key objective.

\subsection{Attitudes Towards Economic Performance}

As shown in Table 7, the hypothetical positive relationship between the attitude towards economic performance (ATEP) of SHET and adoption intention is rejected, meaning that residents' perceptions of economic performance of SHET, such as financial gains through saving energy, cost-efficiency, or low maintenance cost, would not lead residents to adopt these products. This empirical result contradicts with the assumption of traditional economics that human will make rational choices after weighing the benefits and costs [96]. Not uniquely, plenty of previous research has also reported similar findings, for example, Hobman [97] described that only a small minority of Australian customers participated in a cost-reflective electricity tariff program, even it was successful in reducing the peak demand and electricity expense; Anderson [98] analyzed the technology adoption decisions made by manufacture plants after a government-funded energy audits, and noted that half of the energy efficiency projects were rejected by plants even if the project payback period were remarkably short; Allcott [99] pointed out that people fail to adopt those energy technologies which can help them save money, such as better insulation, or efficient domestic appliances and lighting. All these studies suggest that even people have perceived the profitable and cost effective of energy technologies, their decisions might still lead to a lower technology diffusion rate. This phenomenon is named as "Energy Efficiency Gap" [100-102], as it derives from consumer's irrational choice that not consistent with assumptions of traditional economics, burgeoning of literature has begun to discuss this phenomenon under the theory of behavioral economics $[100,103]$.

Back to the results of this study, as shown by Table 3, the characteristics of the majority of respondents, including middle-young age (93.2\% are $18-60$ years old), well educated $(63.8 \%$ have university degree or above) and having usage experience of SHET (68.3\%), signified that these urban residents in Guangdong Province exhibit some personal traits of early adopters of energy technology $[28,29,104]$. However, the favorable attitude towards economic performance demonstrated by survey respondents could not lead to the adoption intention (Table 7). In the domain of behavioral economics, the Loss Aversion concept found in Prospect Theory could provide some explanations for this consequence $[105,106]$. Loss aversion refers to people's tendency to weigh more loss than the equivalent gains [106]. Although the residents have perceived the economic gains from usage SHET, they also have concerns about the potential loss from functional risks such as system failure, loss control, 
or privacy leakage; when making decision, they seem to put more value on these risks compared to the potential financial benefit. This explanation is also discussed in the study about adoption of energy efficient technology by homeowners in New Zealand [107], the author suggests homeowners have an asymmetrical perception of risk caused by social and cognitive biases, which prevents them from adopting energy efficiency technologies, regardless how great energy savings they would receive.

Additionally, sunk cost fallacy might be another reason to explain why the hypothetical relationship is not supported. Sunk cost fallacy refers to the tendency to continue a behavior or endeavor once the previously investment was made (time, money or effort) [108]. In the previous decision-making process of energy technology adoption, the sunk cost effect has been observed in both personal and business cases. For example, Verstegen [109] concluded that sunk cost was a significant factor affecting the adoption of energy-saving technologies by horticultural farmers based on a survey. Kong [110] recommended that to facilitate the green manufacture technology diffusion through SMEs, governments should provide some financial support to SMEs for adopting the green technologies, until their savings from production could cover the substantial part of the sunk costs. In the context of this study, the residents might have purchased some non-smart or energy-inefficient household appliances before, and those products are still functioning well. Due to the psychology of not wasting resources, those residents would feel reluctant to discard them and replace them with new smart energy efficient products, even though they could perceive the economic benefits from the smart ones. To mitigate this fallacy, the smart home technology companies may consider some marketing strategies to reduce the salience of cost that consumers have already undertook, meanwhile, emphasizing those risks of retaining old household appliances, such as higher energy bill, or growing carbon emission. The industry and government might introduce some policies to reduce the switching cost for consumer from non-smart in-efficient old appliances to smart energy technology, referring to the rebate program for energy-efficient domestic appliances purchase in South Korea [111].

\subsection{Perceived Behavioral Control}

Generally, the perceived behavioral control (PBC) derived from TPB theory is also confirmed to have a positive relationship with the adoption intention of SHET. This finding is also consistent with many discoveries of previous research of energy saving behavior or energy efficient appliance adoption $[19,20,44,49]$. The relationship between PBC with adoption intention reflects the significance of some non-motivational factors [41]. In this study, the non-motivational factors refer to the residents' perceptions about the resources or conditions they own to adopt the smart products, including the knowledge, affordability, and the infrastructural conditions of their houses. The result implies that if residents believe they have more resources or more appropriate conditions to use the smart products, they are more likely to engage.

\subsection{Social Norm}

The positive relationship between social norms and adoption intention is confirmed by this study, which is in line with the backbone theory of planned behavior. This significant relationship implies that residents in Guangdong province would be influenced by the external environments such as government policies, the voices of mass media, and social network when they making decisions to adopt the SHET. This finding is supported by some previous studies about the energy saving or pro-environmental behavior in different regions of China, for example, both Wang [44] and Zhang [112] conducted questionnaire surveys in Shandong Province, and confirmed the significant impacts of government policies, media publicity, education onto the energy saving behavior. Zhao [51] demonstrated the importance of policies and social norms to promote electricity saving behavior in Beijing. Ting [113] asserted the social norms were also applicable in Jiangsu Province in the household energy saving area. Outside of China, the social norm was verified to be an important factor to influence the opportunity of energy saving in American workplaces [41]. The social norm was also found to have a positive relation with purchase intention of energy efficient products in Korea [114]. 
However, some research conducted in other countries such as Pakistan [19] and Malaysia [20] has suggested no positive relationship between the social norm and purchase intention of energy efficient products. The difference of the results between countries might derive from the cultural difference, education level and citizen's perceptions about government enforcement.

\subsection{Personal Norm}

Meanwhile, this study presents positive impact of personal norms onto the adoption intention of SHET. Personal norm is the moral extension of TPB, reflecting the moral dimension of one's internal values. The result implies that residents owning stronger awareness of energy saving would be more possible to adopt SHET. The indicators reflecting personal norm include the social responsibility and environmental concern, which shares the similar results of some passed research of energy saving behavior $[20,44,47,48]$ Additionally, because of the innovativeness of smart technology, one indicator reflecting one's interest about technology innovation is also employed to measure residents' internal values towards the smart technology innovation. The result confirms the reliability of this indicator. This finding echoes with the study of Ali [19], that the residents who have positive attitude towards the technology and innovation have higher intention to adoption energy efficient household appliances.

\subsection{The Influence of Demographic Factor}

\subsubsection{Gender}

In this study, the gender difference lies in the H5: the positive relationship between personal norm and adoption intention is supported by the male group while rejected by the female one. This finding about gender difference is consistent with the viewpoint of one literature which asserted "Chinese men show greater environmental awareness than Chinese woman" [115]. However, in the context of western countries, it seems no consensus about the impact of gender difference onto the environmental concerns. Some research reported that women had stronger belief about pro-environmental behavior, while some studies found no relationship [116]. Therefore, the influence of gender factor on the people's adoption intention of SHET needs furtherly survey and study.

\subsubsection{Age}

As shown by Table 8 , the hypothesis test results are dominated by the group of young and middle aged adults, because of their higher proportion (93.2\%). However, the analysis of juvenile and old groups presents some different outcomes. All five hypotheses are rejected by the assessment result of the old group, indicating the theoretical model discussed in this paper is totally not applicable to elderly adults. With the coming of an aging society, plenty of research have emerged to study the adoption of smart technology especially for the older adults, and compared to the energy saving, the elder value more on the function of assisted living, such as personal emergency alarm, which could help them to live in their homes independently [117].

As for juveniles, compared to the adults, the only factor empirically supporting their adoption intention is ATTP, with the other four hypotheses $\mathrm{H} 2-\mathrm{H} 5$ being rejected. This consequence maybe be due to the widespread popularity of smartphones and mobile internet. Teenagers don't perceive smart technology as strange, thus they could have positive perceptions about the technology performance, nevertheless, due to the lacking of enough knowledge and skills, no financial capability, and immature personal values, the juveniles could not build positive relationships between another four factors and the adoption intention.

\subsubsection{Education}

The assessment result of sub-group with university degree and above is consistent with the hypothesis test result of the whole group, while the analysis of the sub-group without bachelor degrees presents slightly differences. At the significance level of ${ }^{*} p<0.05, \mathrm{H} 1$ is rejected by the low educational 
level group. One explanation might be that due to their knowledge limitations, it is hard for them to have positive perceptions about complicated technology performance. This explanation is also supported by the research of Mills [118]. In his study of resident energy efficient technology adoption in European countries, he concluded that education level had a strong impact on family's attitude towards energy efficiency technology. To solve this problem, government or industry organizations might hold some training course to foster the perceptions or understands of smart technology by people with lower education background.

\subsubsection{Personal Income}

$\mathrm{H} 1-\mathrm{H} 5$ are also examined for the sub-groups of poor, middle class and affluent, respectively. The assessment results in Table 8 reveal that there is no difference between the poor and middle class, consistent with the results of the whole group. Nevertheless, the hypothesis test result of the affluent group deviates from the others very much. As shown by Table 8, in contrast with all other sub-groups, $\mathrm{H} 2$ is empirically verified for the 169-sample size affluent people, which indicates that the rich people intend to use SHET as if they can perceive the positive economic performance of SHET. Compared to the poor and middle class, rich people are less likely to be trapped in an "Energy Efficiency Gap". This discovery echoes a view from behavior economics research related with poverty, that affluent people are less possible to suffer the behavior [119]. What is more, H1 is also supported by the affluent, the same with the poor and middle class, but $\mathrm{H} 3-\mathrm{H} 5$ are all rejected. This consequence reveals that the affluent respondents in this study are solely goal and profit driven. The only two factors they consider for the SHET adoption are the technical performance and economic benefits, and they are not concerned with factors like external resources, conditions, social or personal norms.

\section{Conclusions}

This study developed a research model to explore the factors influencing resident' intentions to adopt smart home energy technology in Guangdong Province in China. The theory of planned behavior (TPB) was employed as the backbone theory of the model, and the norm activation model (NAM) was combined to improve model's explaining power about the moral dimension. Because of the innovativeness and special technical features of smart technology, the construct of attitude in TPB was replaced by attitude towards technical performance (ATTP) and attitude towards economic performance (ATEP) separately. Generally, the study pays attention to the relationship between the attitude towards technical performance/economic performance, social norm, perceived behavioral control, personal norm and adoption intention of SHET by residents in Guangdong, which we have justified as a good exemplary case for China's situation. In order to examine the model, a questionnaire survey was organized in Guangdong to collect data, and the structural equation modelling technique using PLS was employed to conduct data analysis and research hypothesis test.

The analysis results indicated that four hypotheses were supported while one was rejected, confirming the positive relationship between attitude towards technical performance (ATTP), social norm (SN), perceived behavior control (PBC), personal norm $(\mathrm{PN})$ and the adoption intention of SHET. However, the positive impact of attitude towards economic performance on adoption intention was rejected, and two explanations deriving from behavioral economics were proposed to explain this consequence.

With the purpose of investigating the impact of demographic factor on the adoption intention, the whole data group was divided into several sub-groups by the category of demographic information and re-modeled by PLS-SEM. The comparisons of the assessment result for each sub-group discovered some differences among each categorical groups: the gender difference lay in the factor of personal norm; the adoption intention of teenagers would be solely driven by their positive perceptions of technology performance; the theoretical model was totally not applicable to the old people; the educational level could affect resident's attitude towards the technical performance, and the high income group only considered two attitude factors when making adoption decisions. 
Some limitations existing in this study should be acknowledged. The first is that TPB and NAM are the backbone theories adopted by this study, so the factors and measurement indicator are confined under the framework of the two theories. However, as the complexity of human behavior, the adoption intention may also be affected by some other factors neither associated with backbone theory nor mentioned by the study. Secondly, the research data were collected from self-reporting questionnaire, rather than the observation of actual behavior, therefore the respondent's answers may be influenced by some inherent bias resulting from personal characters, society environment, or demographic factors, but not the real situations. Third, the descriptive analysis result showed that only $3.3 \%$ of the respondents are elderly people. As China is gradually becoming an aging society, more and more requirements of the elderly should be considered in future. Finally, in the analysis for demographic factors, the sample size of some categorical groups are not compatible with each other; although PLS-SEM does not require the large enough data sample, it still lacks some preciseness and need further efforts.

Author Contributions: Conceptualization, methodology, formal analysis, investigation, writing-W.J.; writing - review and editing, supervisor, E.H.W.C.

Funding: This research is funded by Research Institute for Sustainable Urban Development (RISUD) and Department of Building and Real Estate of the Hong Kong Polytechnic University.

Acknowledgments: Special thanks to Research Institute for Sustainable Urban Development (RISUD) and Department of Building and Real Estate of the Hong Kong Polytechnic University.

Conflicts of Interest: The authors declare no conflict of interest.

\section{References}

1. The International Energy Agency. World Energy Outlook 2017; The International Energy Agency: Paris, France, 2017.

2. Karytsas, S.; Vardopoulos, I.; Theodoropoulou, E. Factors Affecting Sustainable Market Acceptance of Residential Microgeneration Technologies. A Two Time Period Comparative Analysis. Energies 2019, 12, 3298. [CrossRef]

3. Lobaccaro, G.; Carlucci, S.; Löfström, E. A Review of Systems and Technologies for Smart Homes and Smart Grids. Energies 2016, 9, 348. [CrossRef]

4. Marikyan, D.; Papagiannidis, S.; Alamanos, E. A systematic review of the smart home literature: A user perspective. Technol. Forecast. Soc. Chang. 2019, 138, 139-154. [CrossRef]

5. Zhou, B.; Li, W.; Chan, K.W.; Cao, Y.; Kuang, Y.; Liu, X.; Wang, X. Smart home energy management systems: Concept, configurations, and scheduling strategies. Renew. Sustain. Energy Rev. 2016, 61, 30-40. [CrossRef]

6. Karlin, B.; Ford, R.; Sanguinetti, A.; Squiers, C.; Gannon, J.; Rajukumar, M.; Donnelly, K.A. Characterization and Potential of Home Energy Management (hem) Technology; Pacific Gas and Electric: San Francisco, CA, USA, 2015.

7. Ford, R.; Pritoni, M.; Sanguinetti, A.; Karlin, B. Categories and functionality of smart home technology for energy management. Build. Environ. 2017, 123, 543-554. [CrossRef]

8. Balta-Ozkan, N.; Boteler, B.; Amerighi, O. European smart home market development: Public views on technical and economic aspects across the United Kingdom, Germany and Italy. Energy Res. Soc. Sci. 2014, 3, 65-77. [CrossRef]

9. Innovation and Technology Bureau. Hong Kong Smart City Blueprint; Innovation and Technology Bureau: Hong Kong, China, 2017.

10. Bhati, A.; Hansen, M.; Chan, C.M. Energy conservation through smart homes in a smart city: A lesson for Singapore households. Energy Policy 2017, 104, 230-239. [CrossRef]

11. Vassileva, I.; Dahlquist, E.; Wallin, F.; Campillo, J. Energy consumption feedback devices' impact evaluation on domestic energy use. Appl. Energy 2013, 106, 314-320. [CrossRef]

12. Tang, S.; Kalavally, V.; Ng, K.Y.; Parkkinen, J.; Yew, N.K. Development of a prototype smart home intelligent lighting control architecture using sensors onboard a mobile computing system. Energy Build. 2017, 138, 368-376. [CrossRef]

13. Beaudin, M.; Zareipour, H. Home energy management systems: A review of modelling and complexity. Renew. Sustain. Energy Rev. 2015, 45, 318-335. [CrossRef] 
14. Seligman, C.; Darley, J.M. Feedback as a means of decreasing residential energy consumption. J. Appl. Psychol. 1977, 62, 363-368. [CrossRef]

15. Louis, J.-N.; Caló, A.; Leiviskä, K.; Pongrácz, E. Environmental Impacts and Benefits of Smart Home Automation: Life Cycle Assessment of Home Energy Management System. IFAC PapersOnLine 2015, 48, 880-885. [CrossRef]

16. Balta-Ozkan, N.; Davidson, R.; Bicket, M.; Whitmarsh, L. Social barriers to the adoption of smart homes. Energy Policy 2013, 63, 363-374. [CrossRef]

17. Park, E.-S.; Hwang, B.; Ko, K.; Kim, D. Consumer Acceptance Analysis of the Home Energy Management System. Sustainability 2017, 9, 2351. [CrossRef]

18. Wang, Z.; Wang, X.; Guo, D. Policy implications of the purchasing intentions towards energy-efficient appliances among China's urban residents: Do subsidies work? Energy Policy 2017, 102, 430-439. [CrossRef]

19. Ali, S.; Ullah, H.; Akbar, M.; Akhtar, W.; Zahid, H. Determinants of Consumer Intentions to Purchase Energy-Saving Household Products in Pakistan. Sustainability 2019, 11, 1462. [CrossRef]

20. Tan, C.-S.; Ooi, H.-Y.; Goh, Y.-N. A moral extension of the theory of planned behavior to predict consumers' purchase intention for energy-efficient household appliances in Malaysia. Energy Policy 2017, 107, 459-471. [CrossRef]

21. Zhou, N. Energy for 500 Million Homes: Drivers and Outlook for Residential Energy Consumption in China; Lawrence Berkeley National Lab.(LBNL): Berkeley, CA, USA, 2009.

22. Smart Home-Worldwide. Available online: https:/www.statista.com/outlook/279/100/smart-home/ worldwide (accessed on 30 October 2019).

23. Kroll, H.; Tagscherer, U. Chinese regional innovation systems in times of crisis: The case of Guangdong. Asian J. Technol. Innov. 2009, 17, 101-128. [CrossRef]

24. Guangdong 13th Five-Year Plan for Building Energy Conservation and Green Building Development. 2017. Available online: http://zfcxjst.gd.gov.cn/xwzx/rdgz/content/post_1390708.html (accessed on 30 October 2019).

25. Cheng, B.; Dai, H.; Wang, P.; Xie, Y.; Chen, L.; Zhao, D.; Masui, T. Impacts of low-carbon power policy on carbon mitigation in Guangdong Province, China. Energy Policy 2016, 88, 515-527. [CrossRef]

26. 13th Five-Year Smart Grid Development Plan of China Southern Power Grid. 2017. Available online: https://www.csg.cn/xwzx/2017/gsyw/201708/t20170822_159482.html (accessed on 22 August 2017).

27. National Bureau of Statistics of China, Guangdong Provincial Data. 2018. Available online: http://data.stats. gov.cn/easyquery.htm?cn=E0103\&zb=A0201\&reg=440000\&sj=2018 (accessed on 30 October 2019).

28. Rogers, E.M. Diffusion of Innovations; Simon and Schuster: New York, NY, USA, 2010.

29. Venkatesh, V.; Morris, M.G.; Davis, G.B.; Davis, F.D. User Acceptance of Information Technology: Toward a Unified View. MIS Q. 2003, 27, 425. [CrossRef]

30. Mahapatra, K.; Gustavsson, L. An adopter-centric approach to analyze the diffusion patterns of innovative residential heating systems in Sweden. Energy Policy 2008, 36, 577-590. [CrossRef]

31. Willis, K.; Scarpa, R.; Gilroy, R.; Hamza, N. Renewable energy adoption in an ageing population: Heterogeneity in preferences for micro-generation technology adoption. Energy Policy 2011, 39, 6021-6029. [CrossRef]

32. Yang, W.; Lam, P.T. Non-market valuation of consumer benefits towards the assessment of energy efficiency gap. Energy Build. 2019, 184, 264-274. [CrossRef]

33. Ajzen, I. The theory of planned behavior. Organ. Behav. Hum. Decis. Process. 1991, 50, 179-211. [CrossRef]

34. Schwartz, S.H. Normative explanations of helping behavior: A critique, proposal, and empirical test. J. Exp. Soc. Psychol. 1973, 9, 349-364. [CrossRef]

35. Onwezen, M.C.; Antonides, G.; Bartels, J. The Norm Activation Model: An exploration of the functions of anticipated pride and guilt in pro-environmental behaviour. J. Econ. Psychol. 2013, 39, 141-153. [CrossRef]

36. Han, H. The norm activation model and theory-broadening: Individuals' decision-making on environmentally-responsible convention attendance. J. Environ. Psychol. 2014, 40, 462-471. [CrossRef]

37. Schwartz, S.H. Normative Influences on Altruism, in Advances in Experimental Social Psychology; Elsevier: Amsterdam, The Netherlands, 1977; pp. 221-279.

38. Harland, P.; Staats, H.; Wilke, H.A.M. Explaining Proenvironmental Intention and Behavior by Personal Norms and the Theory of Planned Behavior1. J. Appl. Soc. Psychol. 1999, 29, 2505-2528. [CrossRef]

39. Schwartz, S.H. Words, deeds and the perception of consequences and responsibility in action situations. J. Pers. Soc. Psychol. 1968, 10, 232-242. [CrossRef] 
40. De Groot, J.I.M.; Steg, L. Morality and Prosocial Behavior: The Role of Awareness, Responsibility, and Norms in the Norm Activation Model. J. Soc. Psychol. 2009, 149, 425-449. [CrossRef]

41. Li, D.; Xu, X.; Chen, C.-F.; Menassa, C. Understanding energy-saving behaviors in the American workplace: A unified theory of motivation, opportunity, and ability. Energy Res. Soc. Sci. 2019, 51, 198-209. [CrossRef]

42. Stern, P.C. What psychology knows about energy conservation. Am. Psychol. 1992, 47, 1224-1232. [CrossRef]

43. Barr, S.; Gilg, A.W.; Ford, N. The household energy gap: Examining the divide between habitual- and purchase-related conservation behaviours. Energy Policy 2005, 33, 1425-1444. [CrossRef]

44. Wang, B.; Wang, X.; Guo, D.; Zhang, B.; Wang, Z. Analysis of factors influencing residents' habitual energy-saving behaviour based on NAM and TPB models: Egoism or altruism? Energy Policy 2018, 116, 68-77. [CrossRef]

45. Gyberg, P.; Palm, J. Influencing households' energy behaviour-How is this done and on what premises? Energy Policy 2009, 37, 2807-2813. [CrossRef]

46. Shi, H.; Fan, J.; Zhao, D. Predicting household $\mathrm{PM}_{2.5}$-reduction behavior in Chinese urban areas: An integrative model of Theory of Planned Behavior and Norm Activation Theory. J. Clean. Prod. 2017, 145, 64-73. [CrossRef]

47. Lopes, J.R.N.; de Araújo Kalid, R.; Rodríguez, J.L.M.; Ávila Filho, S. A new model for assessing industrial worker behavior regarding energy saving considering the theory of planned behavior, norm activation model and human reliability. Resour. Conserv. Recycl. 2019, 145, 268-278. [CrossRef]

48. Chen, M.-F. Extending the theory of planned behavior model to explain people's energy savings and carbon reduction behavioral intentions to mitigate climate change in Taiwan-moral obligation matters. J. Clean. Prod. 2016, 112, 1746-1753. [CrossRef]

49. Zhang, X.; Geng, G.; Sun, P. Determinants and implications of citizens' environmental complaint in China: Integrating theory of planned behavior and norm activation model. J. Clean. Prod. 2017, 166, 148-156. [CrossRef]

50. Ivancevich, J.M.; Matteson, M.T. Stress and Work: A Managerial Perspective; Scott Foresman: Glenview, IL, USA, 1980.

51. Wang, Z.; Zhang, B.; Yin, J.; Zhang, Y. Determinants and policy implications for household electricity-saving behaviour: Evidence from Beijing, China. Energy Policy 2011, 39, 3550-3557. [CrossRef]

52. Liu, Y.; Hong, Z.; Zhu, J.; Yan, J.; Qi, J.; Liu, P. Promoting green residential buildings: Residents' environmental attitude, subjective knowledge, and social trust matter. Energy Policy 2018, 112, 152-161. [CrossRef]

53. Cook, D.J. How Smart Is Your Home? Science 2012, 335, 1579-1581. [CrossRef] [PubMed]

54. Wong, J.K.W.; Leung, J.K. Modelling factors influencing the adoption of smart-home technologies. Facilities 2016, 34, 906-923. [CrossRef]

55. Mert, W.; Tritthart, W. Get smart! Consumer acceptance and restrictions of Smart Domestic Appliances in Sustainable Energy Systems. In Proceedings of the TRANSPOSE Midterm Conference, Turku, Finland, 29 November 2018.

56. Wong, J.K.W.; Leung, J.; Skitmore, M.; Buys, L. Technical requirements of age-friendly smart home technologies in high-rise residential buildings: A system intelligence analytical approach. Autom. Constr. 2017, 73, 12-19. [CrossRef]

57. Paetz, A.-G.; Dütschke, E.; Fichtner, W. Smart Homes as a Means to Sustainable Energy Consumption: A Study of Consumer Perceptions. J. Consum. Policy 2012, 35, 23-41. [CrossRef]

58. Balta-Ozkan, N.; Davidson, R.; Bicket, M.; Whitmarsh, L. The development of smart homes market in the UK. Energy 2013, 60, 361-372. [CrossRef]

59. Balta-Ozkan, N.; Amerighi, O.; Boteler, B. A comparison of consumer perceptions towards smart homes in the UK, Germany and Italy: Reflections for policy and future research. Technol. Anal. Strat. Manag. 2014, 26, 1176-1195. [CrossRef]

60. Ringel, M.; Laidi, R.; Djenouri, D. Multiple Benefits through Smart Home Energy Management Solutions-A Simulation-Based Case Study of a Single-Family-House in Algeria and Germany. Energies 2019, 12, 1537. [CrossRef]

61. Wisdom, J.P.; Chor, K.H.B.; Hoagwood, K.E.; Horwitz, S.M. Innovation adoption: A review of theories and constructs. Adm. Policy Ment. Heal. Ment. Heal. Serv. Res. 2014, 41, 480-502. [CrossRef]

62. Hori, S.; Kondo, K.; Nogata, D.; Ben, H. The determinants of household energy-saving behavior: Survey and comparison in five major Asian cities. Energy Policy 2013, 52, 354-362. [CrossRef] 
63. Chiou, J.-S. The effects of attitude, subjective norm, and perceived behavioral control on consumers' purchase intentions: The moderating effects of product knowledge and attention to social comparison information. Proc. Natl. Sci. Counc. ROC 1998, 9, 298-308.

64. Park, J.; Ha, S. Understanding Consumer Recycling Behavior: Combining the Theory of Planned Behavior and the Norm Activation Model. Fam. Consum. Sci. Res. J. 2014, 42, 278-291. [CrossRef]

65. Hamann, K.R.; Reese, G.; Seewald, D.; Loeschinger, D.C. Affixing the theory of normative conduct (to your mailbox): Injunctive and descriptive norms as predictors of anti-ads sticker use. J. Environ. Psychol. 2015, 44, 1-9. [CrossRef]

66. Cialdini, R.B.; Reno, R.R.; Kallgren, C.A. A focus theory of normative conduct: Recycling the concept of norms to reduce littering in public places. J. Pers. Soc. Psychol. 1990, 58, 1015-1026. [CrossRef]

67. Wang, Z.; Zhang, B.; Li, G. Determinants of energy-saving behavioral intention among residents in Beijing: Extending the theory of planned behavior. J. Renew. Sustain. Energy 2014, 6, 053127. [CrossRef]

68. Zhang, L.; Chen, L.; Wu, Z.; Xue, H.; Dong, W. Key Factors Affecting Informed Consumers' Willingness to Pay for Green Housing: A Case Study of Jinan, China. Sustainability 2018, 10, 1711. [CrossRef]

69. Brody, S.; Grover, H.; Vedlitz, A. Examining the willingness of Americans to alter behaviour to mitigate climate change. Clim. Policy 2012, 12, 1-22. [CrossRef]

70. Agarwal, R.; Prasad, J. A Conceptual and Operational Definition of Personal Innovativeness in the Domain of Information Technology. Inf. Syst. Res. 1998, 9, 204-215. [CrossRef]

71. Wong, J.; Li, H.; Lai, J. Evaluating the system intelligence of the intelligent building systems: Part 1: Development of key intelligent indicators and conceptual analytical framework. Autom. Constr. 2008, 17, 284-302. [CrossRef]

72. Karlin, B.; Zinger, J.F.; Ford, R. The effects of feedback on energy conservation: A meta-analysis. Psychol. Bull. 2015, 141, 1205-1227. [CrossRef]

73. Tan, T.H. Use of Structural Equation Modeling to Predict the Intention to Purchase Green and Sustainable Homes in Malaysia. Asian Soc. Sci. 2013, 9, 181. [CrossRef]

74. Yadav, R.; Pathak, G.S. Young consumers' intention towards buying green products in a developing nation: Extending the theory of planned behavior. J. Clean. Prod. 2016, 135, 732-739. [CrossRef]

75. Judge, M.; Warren-Myers, G.; Paladino, A. Using the theory of planned behaviour to predict intentions to purchase sustainable housing. J. Clean. Prod. 2019, 215, 259-267. [CrossRef]

76. Hair, J.F.; Ringle, C.M.; Sarstedt, M. Partial Least Squares: The Better Approach to Structural Equation Modeling? Long Range Plan. 2012, 45, 312-319. [CrossRef]

77. Fornell, C.; Bookstein, F.L. Two Structural Equation Models: LISREL and PLS Applied to Consumer Exit-Voice Theory. J. Mark. Res. 1982, 19, 440-452. [CrossRef]

78. Lee, L.; Petter, S.; Fayard, D.; Robinson, S. On the use of partial least squares path modeling in accounting research. Int. J. Acc. Inf. Syst. 2011, 12, 305-328. [CrossRef]

79. Hair, J.F.; Ringle, C.M.; Sarstedt, M. Partial Least Squares Structural Equation Modeling: Rigorous Applications, Better Results and Higher Acceptance. Long Range Plan. 2013, 46, 1-12. [CrossRef]

80. Lowry, P.B.; Gaskin, J. Partial Least Squares (PLS) Structural Equation Modeling (SEM) for Building and Testing Behavioral Causal Theory: When to Choose It and How to Use It. IEEE Trans. Dependable Secur. Comput. 2014, 57, 123-146. [CrossRef]

81. Akter, S.; Wamba, S.F.; Dewan, S. Why PLS-SEM is suitable for complex modelling? An empirical illustration in big data analytics quality. Prod. Plan. Control. 2017, 28, 1011-1021. [CrossRef]

82. Hulland, J. Use of partial least squares (PLS) in strategic management research: A review of four recent studies. Strat. Manag. J. 1999, 20, 195-204. [CrossRef]

83. Hair, J.; Hollingsworth, C.L.; Randolph, A.B.; Chong, A.Y.L. An updated and expanded assessment of PLS-SEM in information systems research. Ind. Manag. Data Syst. 2017, 117, 442-458. [CrossRef]

84. Rigdon, E.E. Choosing PLS path modeling as analytical method in European management research: A realist perspective. Eur. Manag. J. 2016, 34, 598-605. [CrossRef]

85. Sarstedt, M.; Ringle, C.M.; Smith, D.; Reams, R.; Hair, J.F. Partial least squares structural equation modeling (PLS-SEM): A useful tool for family business researchers. J. Fam. Bus. Strat. 2014, 5, 105-115. [CrossRef]

86. Usakli, A.; Kucukergin, K.G. Using partial least squares structural equation modeling in hospitality and tourism: Do researchers follow practical guidelines? Int. J. Contemp. Hosp. Manag. 2018, 30, 3462-3512. [CrossRef] 
87. Aibinu, A.A.; Al-Lawati, A.M. Using PLS-SEM technique to model construction organizations' willingness to participate in e-bidding. Autom. Constr. 2010, 19, 714-724. [CrossRef]

88. Hair, J.F.; Sarstedt, M.; Ringle, C.M.; Mena, J.A. An assessment of the use of partial least squares structural equation modeling in marketing research. J. Acad. Mark. Sci. 2012, 40, 414-433. [CrossRef]

89. Ringle, C.M.; Wende, S.; Becker, J.-M. SmartPLS 3. 2015. Available online: http://www.smartpls.com (accessed on 30 August 2019).

90. Hair, J.F.; Hult, G.T.M.; Ringle, C.; Sarstedt, M. A Primer on Partial Least Squares Structural Equation Modeling (PLS-SEM); Sage Publications: Thousand Oaks, CA, USA, 2016.

91. Hair, J.F.; Ringle, C.M.; Sarstedt, M. PLS-SEM: Indeed a silver bullet. J. Mark. Theory Pract. 2011, 19, $139-152$. [CrossRef]

92. Hair, J.F.; Matthews, L.M.; Matthews, R.L.; Sarstedt, M. PLS-SEM or CB-SEM: Updated guidelines on which method to use. Int. J. Multivar. Data Anal. 2017, 1, 107-123. [CrossRef]

93. Cohen, J. Statistical Power Analysis for the Behavioral Sciences; Routledge: London, UK, 1983.

94. Davis, F.D. Perceived Usefulness, Perceived Ease of Use, and User Acceptance of Information Technology. MIS Q. 1989, 13, 319. [CrossRef]

95. Davis, F.D.; Bagozzi, R.P.; Warshaw, P.R. User Acceptance of Computer Technology: A Comparison of Two Theoretical Models. Manag. Sci. 1989, 35, 982-1003. [CrossRef]

96. Simon, H.A. A Behavioral Model of Rational Choice. Q. J. Econ. 1955, 69, 99. [CrossRef]

97. Hobman, E.V.; Frederiks, E.R.; Stenner, K.; Meikle, S. Uptake and usage of cost-reflective electricity pricing: Insights from psychology and behavioural economics. Renew. Sustain. Energy Rev. 2016, 57, 455-467. [CrossRef]

98. Anderson, S.T.; Newell, R.G. Information programs for technology adoption: The case of energy-efficiency audits. Resour. Energy Econ. 2004, 26, 27-50. [CrossRef]

99. Allcott, H.; Mullainathan, S. Behavior and Energy Policy. Science 2010, 327, 1204-1205. [CrossRef]

100. Gillingham, K.; Palmer, K. Bridging the Energy Efficiency Gap: Policy Insights from Economic Theory and Empirical Evidence. Rev. Environ. Econ. Policy 2014, 8, 18-38. [CrossRef]

101. Hirst, E.; Brown, M. Closing the efficiency gap: Barriers to the efficient use of energy. Resour. Conserv. Recycl. 1990, 3, 267-281. [CrossRef]

102. Jaffe, A.B.; Stavins, R.N. The energy-efficiency gap What does it mean? Energy Policy 1994, 22, 804-810. [CrossRef]

103. Frederiks, E.R.; Stenner, K.; Hobman, E.V. Household energy use: Applying behavioural economics to understand consumer decision-making and behaviour. Renew. Sustain. Energy Rev. 2015, 41, 1385-1394. [CrossRef]

104. Campbell, A.R.; Ryley, T.; Thring, R. Identifying the early adopters of alternative fuel vehicles: A case study of Birmingham, United Kingdom. Transp. Res. Part A Policy Pract. 2012, 46, 1318-1327. [CrossRef]

105. Kahneman, D.; Knetsch, J.L.; Thaler, R.H. Anomalies: The Endowment Effect, Loss Aversion, and Status Quo Bias. J. Econ. Perspect. 1991, 5, 193-206. [CrossRef]

106. Tversky, A.; Kahneman, D. Advances in prospect theory: Cumulative representation of uncertainty. J. Risk Uncertain. 1992, 5, 297-323. [CrossRef]

107. Christie, L.; Donn, M.; Walton, D. The 'apparent disconnect' towards the adoption of energy-efficient technologies. Build. Res. Inf. 2011, 39, 450-458. [CrossRef]

108. Arkes, H.R.; Blumer, C. The psychology of sunk cost. Organ. Behav. Hum. Decis. Process. 1985, 35, $124-140$. [CrossRef]

109. Verstegen, J.A.A.M.; Sonnemans, J.; Oskam, A.J.; Huirne, R.B.M. Investigating adoption of energy-saving technologies in greenhouse horticulture. In Proceedings of the Environmental Management System Session of the 14th International Symposium on Horticulture Science, Guernsey, UK, 12-15 September 2000.

110. Kong, D.; Feng, Q.; Zhou, Y.; Xue, L. Local implementation for green-manufacturing technology diffusion policy in China: From the user firms' perspectives. J. Clean. Prod. 2016, 129, 113-124. [CrossRef]

111. Huh, S.-Y.; Jo, M.; Shin, J.; Yoo, S.-H. Impact of rebate program for energy-efficient household appliances on consumer purchasing decisions: The case of electric rice cookers in South Korea. Energy Policy 2019, 129, 1394-1403. [CrossRef]

112. Zhang, C.-Y.; Yu, B.; Wang, J.-W.; Wei, Y.-M. Impact factors of household energy-saving behavior: An empirical study of Shandong Province in China. J. Clean. Prod. 2018, 185, 285-298. [CrossRef] 
113. Yue, T.; Long, R.; Chen, H. Factors influencing energy-saving behavior of urban households in Jiangsu Province. Energy Policy 2013, 62, 665-675. [CrossRef]

114. Janda, S.; Ha, H.-Y.; Ha, H. Predicting consumer intentions to purchase energy-efficient products. J. Consum. Mark. 2012, 29, 461-469.

115. Shields, T.; Zeng, K. The reverse environmental gender gap in China: Evidence from "The China Survey". Soc. Sci. Q. 2012, 93, 1-20. [CrossRef]

116. Stern, P.C.; Dietz, T.; Kalof, L. Value Orientations, Gender, and Environmental Concern. Environ. Behav. 1993, 25, 322-348. [CrossRef]

117. Lee, C. Adoption of Smart Technology Among Older Adults: Challenges and Issues. Public Policy Aging Rep. 2013, 24, 14-17. [CrossRef]

118. Mills, B.; Schleich, J. Residential energy-efficient technology adoption, energy conservation, knowledge, and attitudes: An analysis of European countries. Energy Policy 2012, 49, 616-628. [CrossRef]

119. Bertrand, M.; Mullainathan, S.; Shafir, E. A Behavioral-Economics View of Poverty. Am. Econ. Rev. 2004, 94, 419-423. [CrossRef]

(C) 2019 by the authors. Licensee MDPI, Basel, Switzerland. This article is an open access article distributed under the terms and conditions of the Creative Commons Attribution (CC BY) license (http://creativecommons.org/licenses/by/4.0/). 